\title{
A BRIEF POLITICO-ECONOMIC ANALYSIS OF INDIA SINCE 2014
}

\author{
Mangal Sing Kro ${ }^{1 凶}$ (D) \\ ${ }^{1}$ Assistant Professor, Department of Economics, Lakhimpur Girls' College, Assam, India
}
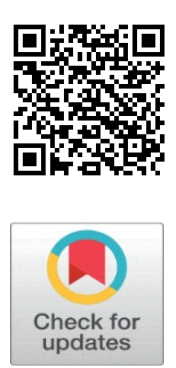

Received 5 August2021

Accepted 20 August 2021

Published 31 August 2021

\section{CorrespondingAuthor \\ Mangal Sing Kro, \\ mangalkro@gmail.com \\ DOI \\ 10.29121/granthaalayah.v9.i8.2021. 4179}

Funding: This research received no specific grant from any funding agency in the public, commercial, or not-for-profit sectors.

Copyright: (C) 2021 The Author(s). This is an open access article distributed under the terms of the Creative Commons Attribution License, which permits unrestricted use, distribution, and reproduction in any medium, provided the original author and source are credited.

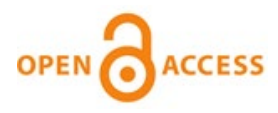

\section{ABSTRACT}

The public representatives have often spoken on the change as well as about New India. What is New India? The answer to this question will depend on the result or the outcome of their actions. The ruling government has been changing and modifying some existing laws and regulations through the parliament imbibing their ideologies. The government which was influenced by neo-liberalists has already privatized some public running enterprises. Many people criticize this ruling government and have called it the less liberal and less democratic style of governance. The questions of freedom associated with religion, expression etc. are often raised by the people during this government.

Keywords: Freedom, Ideology, Liberal, New India and Religion

\section{INTRODUCTION}

India's trend towards neo-liberalism through the way of privatizing public industries and liberalizing government policies in the economic domain is a matter of thorough discussion. The policy of liberalization had started in 1991 (LPG Policy) during the tenure of the former Prime Minister P. V. Narasimha Rao. Neo-liberal economists are in favour of deregulating not only in industrial policies but also in agricultural policies. The Parliament of India had passed Farm Bills 2020 intending to give freedom to the farmers in determining the prices of their produced goods by removing intermediaries. This bill includes (i)Farmers' Produce Trade and Commerce (Promotion and Facilitation) Bill, 2020 (ii) Farmers (Empowerment and Protection) Agreement on Price Assurance and Farm Services Bill, 2020 and (iii) Essential Commodities (Amendment) Bill, 2020 (The Hindu, 2020). However, these bills become controversial and hence, the farmers from different states come out to protest against these bills. These bills theoretically seem to empower farmers, but practically the farmers are afraid of monopsony in the agricultural market. They are also raising the question regarding Minimum Support Price (MSP). The centre has privatized many Indian airports, including Guwahati, Thiruvananthapuram, Jaipur, Lucknow, Ahmedabad and Mangaluru (The Hindu, 2019). This privatization has been done through competitive bidding and therefore, handed over to the highest bidder Adani Enterprises. The neoliberal economists and policymakers are often in favour of transferring ownership rights to the private players rather than suggesting reforms of public sectors by keeping them in the hands of the public itself. They generally believe in raising the efficiency of the firms by transferring 
ownership rights to the private sectors. The transfer of ownership rights to the private players and liberating economic policies provide higher freedom of choice to both consumers and producers. But the privatizing of public enterprises may lead to market failure in many cases.

\section{THE OBJECTIVE OF THE STUDY}

The principal objective of this study is to analyze critically the economic and political dimensions of the government since 2014. Moreover, this paper also tries to investigate on "New India" slogan propagated by the government.

\section{METHODOLOGY AND DISCUSSION}

This is an analytical and descriptive study on the government taking data from secondary sources. This analysis is also based on my observation of the policies and actions taken by this government.

\section{ECONOMIC ANALYSIS}

The government is advocating for New India. What do you mean by New India? Will it be high growth, high employment, low poverty, low undernutrition, high sex ratio, low mortality rate, high social equality, low crimes, high women safety, and low social discrimination and so on? The answer to this question is still not clear if we deeply look into the present economic, social and political scenarios. Is New India for our future? Or is it for political propaganda? If the New India is for the future, then it will remind us about Keynes who said that in the long run, we would die. The growth of the economy of India had been falling even before the COVID pandemic and the announcement of lockdown during this government. Some economists and intellectuals blaming this government for the sudden demonetization announced on November 8, 2016. Moreover, people also blame this government for the improper implementation of GST. The Former Prime Minister, economist Dr Manmohan Singh said that demonetization followed by faulty GST were reasons for the economic slowdown (Business Standard 2019). According to some economists, low aggregate demand is the reason behind the downturn of the economy during that period. The Covid-19 pandemic or the lockdown has added insult to the injury of the economy. The GDP of India contracted by $23.9 \%$ in Q1 (The Hindu, 2020) 7.5\% in the second quarter (July to September) of the financial year 2020-21 due to this lockdown. The present economic problem is not low aggregate demand only; it is also insufficient aggregate supply. The skyrocketing prices of products in the market rather reflect low aggregate supply.

The covid-19 pandemic is multiplying unemployment with the pre-pandemic high unemployment rate. The automobile industry that accounts for $49 \%$ of the country's manufacturing sector was highly affected during the economic slowdown (The Times of India 2019). According to SIAM (Society of Indian Automobile Manufacturers), 3,50,000 jobs were lost and millions of jobs are at risk during the slowdown due to plant shutdown and bankruptcy of the dealers (The Times of India 2019). The Covid-19 pandemic makes the bad situation worse. A huge pandemic created unemployed were suffering from the insecurity of food, inability to access health service and other basic needs. A huge number of interstate migrant workers were obliged to walk back to their homes thousands of miles on foot due to the 
insecurity of food, health, shelters and other needs at workplaces due to the lockdown. The present economic condition is not in a good condition. Therefore, it is far away from achieving a 5 trillion-dollar economy.

\section{POLITICAL DIMENSION}

A large section of the Indian voters is still not aware of national policies and their rights. They can be easily moulded by injecting them the religious and caste sentiments although caste and religion are both very sensitive issues in the country. The political parties use it as instruments for political gain. Some national and regional media doing biases toward the parties are threatening to our democratic values. People's belief in media is perhaps becoming narrower and the excess circulation of fake news on social media, like news on Whatsapp, Facebook and YouTube make people confused. Many people raise their voices against the government to protect their freedom of expression. Some people have condemned the arrest of intellectuals and have spoken out on Sedition cases. Some people called this government anti-intellectualism for attacking intellectuals and universities. The Award Wapsi movement started in September 2015 to protest the increasing intolerance in the country against the government. Some people have started questions on the independence and values of some independent national institutions. People also raise their voices against the government for suspending internet connection during the anti-CAA movement in different parts of the country. The Gauhati High Court directed the government of Assam to review the law-andorder situation and asked the government for restoring the mobile internet connection in the state (The Telegraph 2019). Many people called the Citizenship (Amendment) Act, 2019 non-secular. Joe Biden, the present President of the USA once expressed his disappointment over the Citizenship (Amendment) Act and National Register of Citizens (NRC) which was implemented in Assam (The Hindu, 2020). Social discrimination seems to increase on account of divisive politics. The politics in the name of religion used to hide some issues of the nation, like unemployment, poverty, low economic growth, inflation etc.

\section{CONCLUSION}

The ruling government is changing and modifying economic policies since they came to power in 2014. The government is picking up some industries; privatize them to strengthen the economy. However, some people raise the question of the privatization of the public sector. Some people like to call 'crony capitalism' to this government. Some people have unsatisfactorily expressed their view on its political domain. Some people blaming this government for playing the majority vote bank politics. Many people have started to criticize some institutions which have to be independent. The criticisms of this government often flooded in social media, like Facebook and Twitter. The national media that should be unbiased and neutral are unable to show some national issues of the country seem losing their trustworthiness to some extent. Some people also compare this government with the governments with autocratic style. Therefore, the question standing here for us is what kinds of government will be there in the upcoming days? Will it hold its position as the largest democratic country in the world or it will be changed? Will it be like a less democratic and less secular country? Will it be like crony capitalism and the autocratic style of the government? The actions of the government will provide these answers. 


\section{REFERENCES}

Biden seeks restoration of peoples' rights in Kashmir; disappointed with CAA, NRC. (2020), (June 26) The Hindu. Retrieved from https://www.thehindu.com/news/international/biden-seeks-restorationof-peoples-rights-in-kashmir-disappointed-with-caanrc/article31921284.ece

Demonetization followed by faulty GST led to this slowdown: Manmohan Singh. (2019), (September 12). Business Standard, Retrieved from https://www.business-standard.com/article/economy-policy/manmohanslams-govt-over-economy-suggests-5-ways-to-reverse-the-downturn119091200297_1.html

Gauhati HC nudge to restore internet services in Assam. (2019)(, December 17). The Telegraph. Retrieved from https://www.telegraphindia.com/india/courtprod-on-internet-services/cid/1728078\#

Jebaraj, P. (2020), (August 31). GDP contracts by a record 23.9\% in Q1. The Hindu. Retrieved from https://www.thehindu.com/business/Economy/indiasgdp-contracts-by-record-239-in-q1/article32489345.ece

Privatise six more airports: AAI to centre. (2019), (December 1). The Hindu. Retrieved from https://www.thehindu.com/news/national/privatise-sixmore-airports-aai-to-centre/article30131519.ece

Singh, R. (2019), (September 23). Tackling India's auto slowdown: It will hurt the economy and job seriously if corrective steps are not taken. The Times of India. Retrieved from https://timesofindia.indiatimes.com/blogs/toi-editpage/tackling-indias-auto-slowdown-it-will-hurt-the-economy-and-jobsseriously-if-corrective-steps-are-not-taken/

Why are the agriculture bills being opposed? (2020), (September 21). The Hindu. Retrieved from https://www.thehindu.com/news/national/agriculturebills-why-they-are-being opposed/article32660189.ece\#: :text=Two\%20of\%20the\%20three\%20c ontroversials,Rajya $\% 20$ Sabha $\% 20$ on $\% 20$ September\%2020.\&text=Since $\%$ 20 agriculture $\% 20$ and $\% 20$ markets $\% 20$ are,the $\% 20$ spirit $\% 20$ of $\% 20$ cooper ative $\% 20$ federalism 